\title{
OECD DAC의 ODA 현대화 논의 \\ : 민간재원 동원 및 측정을 중심으로
}

목차

I. 서론

II. 민간재원 동원·측정 관련 ODA 현대화 기본원칙 소개

1. ODA 차관 측정방식 변경

2. 신규 금융수단의 도입

3. 공적지원으로 인해 동원된 민간재원 측정

4. 민간금융수단(Private-Sector Instruments)의 측정

5. TOSSD의 도입

III. 시사점 및 결론

1. 민간자금 차입을 통한 ODA 차관의 증가 가능성

2. 공적지원으로 인해 동원된 민간재원 측정 범위 확대 필요

3. 신규 금융수단 및 민간금융수단을 활용한 사업 다각화 필요

4. TOSSD의 도입으로 인한 ODA 실질 감소 우려 및 구체화 필요

5. 통계 고도화 및 다변화

주제어: $\mathrm{ODA}$ 현대화, $\mathrm{ODA}$ 재정의, 민간재원 동원, 민간금융수단(PSI), TOSSD 


\section{I. 서론}

$\mathrm{ODA}$ 현대화 논의는 변화하고 있는 국제개발협력 지형을 보다 정확하게 파악하고 반영하고자 하는 수요에서 시작되었다. 먼저 개도국으로 유입되는 자금 중 ODA가 차지하는 규모가 2012년 기준 약 1,350 억 달러로 전체의 $28 \%$ 로, 60 년대 후반에는 $\mathrm{ODA}$ 비중이 $50 \%$ 에 달했던 점을 고려 하면 개도국 유입 재원에서 $\mathrm{ODA}$ 의 역할이 크게 축소되었다.

한편, 기존의 $\mathrm{OECD} \mathrm{DAC} \mathrm{회원국} \mathrm{중심의} \mathrm{공여국들이} \mathrm{전통적인} \mathrm{방식으로} \mathrm{제공해오던} \mathrm{개발을} \mathrm{위}$ 한 공적재원의 공급 상황이 불투명해진 반면, 개발을 위해 필요한 재원 수요는 증가하는 상황에 서 이러한 재원의 수요, 공급 간의 격차를 해소하는 방안이 시급히 마련되어야할 필요성이 대두 됨에 따라, 개도국 조세수익 증대, 신흥공여국의 기여제고, 민간재원과의 결합 등을 통한 재원의 다각화와 양적 확대방안이 논의되기 시작했다.

이러한 변화된 개발지형 속에서 ODA 정의 현대화와 새로운 지원방식·금융수단의 측정방법 마 련의 필요성이 대두되었고, 특히 최근 국제금융위기와 세계적인 저금리 기조 등 $\mathrm{ODA}$ 를 둘러싼 환경변화에 따라 $\mathrm{ODA}$ 정의 및 통계 측정 방안에 대한 수정 논의 필요성이 강하게 제기되었다. 이에 따라 OECD DAC에서는 2012년 고위급회의(2012 OECD DAC High Level Meeting, 이하 $\mathrm{HLM}$ )의 결정으로 당시 공여국의 노력을 포함한 외부개발재원(external development finance) 이 ODA에 해당하는지 여부를 파악하고, 해당하는 경우 관련 재원을 통계적으로 측정할 수 있는 방법을 고안하는 것이 제안되었고, 이에 따라 $\mathrm{ODA}$ 현대화 논의가 본격적으로 시작되었다.

이렇게 시작된 $\mathrm{ODA}$ 현대화 논의는 $\mathrm{ODA}$ 의 완결성(integrity)을 강화함과 동시에, 총공적개발 재원(Total Official Support for Sustainable Development, 이하 TOSSD)의 도입을 통해 다 각화된 자금 흐름을 포괄적으로 측정하는 방향으로 추진되게 된다. ODA 현대화와 관련한 주요 논의 쟁점 중 민간재원의 동원·측정과 직간접적으로 연관이 있는 사항은 (1) ODA 차관 측정방식 변경(증여등가액 방식 도입 및 양허성 차관에 대한 명확한 기준 마련), (2) 공적지원으로 인해 동 원된 민간재원 측정, (3) 신규 금융수단의 도입, (4) 민간금융수단(private-sector instrument) 측정, (5) TOSSD 도입을 들 수 있다.1) 이 중 현재 대부분의 논의가 2016년 HLM에서 완료되었 으나, (4) 민간금융수단 측정, (5) TOSSD 도입은 아직까지 논의가 계속되고 있는 상황이다. 다음 장에서는 상기 이슈별 변경 사항 및 주요 논의 사항, 그리고 이로 인한 시사점 등을 살펴보도록 하겠다.

1) 이 밖에도 평화안보 관련 ODA 재정의가 논의되어 2016년 HLM 코뮤니케에서 결정된 바 있다. 


\section{II. 민간재원 동원·측정 관련 ODA 현대화 기본원칙 소개}

\section{1. $\mathrm{ODA}$ 차관 측정방식 변경}

2014년부터 시작된 ODA 현대화 작업의 가장 큰 변화는 ODA 차관의 측정방식 변경으로 인한 $\mathrm{ODA}$ 정의 변경이다. 2012년 세계적인 저금리 기조로 인해 $\mathrm{EU}$ 가 저금리로 시장에서 자금을 차 입하여, 개도국에 $\mathrm{ODA}$ 를 제공하는 과정에서 추가적인 예산지원이 없이도 자금 제공이 가능한 경 우가 발생하였고, 이러한 $\mathrm{ODA}$ 차관 제공의 양허성을 인정할 것인지에 대한 논의가 시작되게 되 었다. 또한 차관의 경우 개도국의 상환액을 마이너스(-), 즉 부의 자금 흐름으로 계상함에 따라 궁극적으로 차관 제공국가의 지원액이 ' $O$ '으로 수렴되게 되므로, 이는 ODA 차관 제공 공여국의

노력을 적절하게 반영하지 못한다는 의견이 제기되었다(OECD, 2012b). 이에 따라 OECD DAC 통계작업반을 중심으로 $\mathrm{ODA}$ 차관의 양허성, 증여등가액 측정방식 도입에 관한 논의가 시작되었 으며, 그 결과 다음과 같은 합의에 이르게 된다.

먼저, 차관이 체결된 주체(양자, 다자, 민간)의 구분 없이 ODA 차관이라면 모두 증여등가액을 도입하여 차관 지원액을 측정하는 것으로 변경되었다. 유상 차관 제공 노력도 인정될 수 있도록, 금리상환조건을 고려했을 때 증여에 상당한다고 판단되는 액수(grant equivalency)를 ODA로 인정하는 방식이다. 즉, 증여등가액 방식을 적용할 경우, 현 시점의 양허성 차관 총 지출액 중 양 허적 부분만을 $\mathrm{ODA}$ 로 측정하게 되어, 기존과 같이 차관에 대한 $\mathrm{ODA}$ 가 최종적으로 ' $\mathrm{O}$ '으로 측정 되는 문제가 발생하지 않게 된다.

양자 ODA 차관(sovereign loan)의 경우, 기존에는 $10 \%$ 의 할인율이 단일 적용되던 구조에서, 수원국 소득수준별로 차등할인율이 적용되는 구조로 개편되었다. 즉, 채무상환 리스크가 높은 저 소득국에 지원하는 차관일수록 ODA로 인정되는 증여 상당치(증여액)를 높게 인정받을 수 있도록 $\mathrm{ODA}$ 수원국을 소득별로 3 개 그룹으로 분류하여 각각 $1 \%, 2 \%, 4 \%$ 의 위험조정율 적용(IMF의 고 정할인율 $5 \%+$ 위험조정율 $=$ 할인율 $6 \%, 7 \%, 9 \%)$ 하는 방안을 도입했다 $(\mathrm{OECD}, 2016 \mathrm{c})$. 
〈표 1〉양자 ODA 차관(sovereign loan) 측정방식 변경 상세사항

\begin{tabular}{|c|c|c|}
\hline & 현행 & 변경 \\
\hline 측정방식 & $\begin{array}{l}\text { 순지출방식(cash flows) } \\
\text { 지출액-상환액 }\end{array}$ & $\begin{array}{l}\text { 증여등가액 방식(Grant Equivalent) } \\
\text { 지출액×증여율 }\end{array}$ \\
\hline 최소증여율 & 일괄 25\% & $\begin{array}{l}\text { 소득그룹별 차등 최소증여율 } \\
\text { LDC/LIC : } 45 \%, \text { LMIC: } 15 \%, \text { UMIC: } 10 \%\end{array}$ \\
\hline 할인율 & $\begin{array}{l}\text { 일괄 } 10 \% \\
\text { (위험조정할인율 고려 없음) }\end{array}$ & $\begin{array}{l}\text { 소득그룹별 차등 위험조정할인율 반영 } \\
\text { LDC/LIC : } 9 \%(I M F / W B 5 \%+4 \%) \\
\text { LMIC: } 7 \%(I M F / W B 5 \%+2 \%) \\
\text { UMIC: } 6 \%(I M F / W B 5 \%+1 \%)\end{array}$ \\
\hline
\end{tabular}

출처: 저자 작성

또한, 기존에는 증여율이 $25 \%$ 만 넘으면 양허성을 인정하여 $\mathrm{ODA}$ 로 인정하던 기준에서, 소득그 룹별 차등 증여율 기준을 도입하였다. 채무건전성 확보를 위해 최빈국 및 기타저소득국에 대해서 는 증여율이 $45 \%$ 이상, 중저소득국에 대해서는 증여율이 $15 \%$ 이상, 중고소득국에 대해서는 증여 율이 $10 \%$ 이상인 차관만 $\mathrm{ODA}$ 로 인정하는 방안으로 증여율 기준을 개편하였다(OECD, 2016c). 이와 같은 양자 ODA 차관의 측정 관련 변경사항의 적용은 2018년 ODA 통계부터 상기 변경 안 을 전면 적용(보고시점은 2019년)하고, 2015 17년 ODA에 대해서는 현행 및 신규 측정방식을 병기하되 현행 기준으로 발표하게 된다.

〈표 2〉다자기구 차관 측정방식

\begin{tabular}{|c|c|c|}
\hline & 현행 & 변경 \\
\hline 측정방식 & $\begin{array}{l}\text { 순지출방식(cash flows) } \\
\text { 지출액-상환액 }\end{array}$ & $\begin{array}{l}\text { 증여등가액 방식(Grant Equivalent) } \\
\text { 지출액 × 증여율 }\end{array}$ \\
\hline 최소증여율 & 일괄 25\% & 일괄 10\% \\
\hline 할인율 & $\begin{array}{l}\text { 일괄 } 10 \% \\
\text { (위험조정할인율 고려 없음) }\end{array}$ & $\begin{array}{l}\text { 글로벌 기관 및 다자개발은행(MDBs): 기본할인율 } 5 \% \\
\text { 기타 기구 및 sub-regional 기구: } 6 \% \text { (기본 할인율 } 5 \%+ \\
\text { 위험조정률 } 1 \%)\end{array}$ \\
\hline
\end{tabular}

출처: 저자 작성

한편, $\mathrm{DAC}$ 공여국이 다자기구에 제공한 차관의 $\mathrm{ODA}$ 의 경우, 별도의 할인율 및 증여율 기준 이 필요하다는 회원국의 의견이 제시되었고, 이에 따라 추가적인 논의가 진행된 후 2016년 추가 승인이 되었는데 그 결과는 다음과 같다. 증여등가액 계산을 위한 할인율은 다자기구 범주에 따 라 차별화하기로 하고, 글로벌 기관 및 다자개발은행(MDBs)은 기본할인율 $5 \%$, 기타 기구 및 sub-regional 기구는 기본 할인율 $5 \%$ 에 위험조정률 $1 \%$ 를 더한 $6 \%$ 를 적용하기로 하였다. ODA 적격성 판단을 위한 최소증여율 기준(threshold)은 $10 \%$ 를 적용하기로 결정했다(OECD, 2016b). 


\section{2. 신규 금융수단의 도입}

한편, $\mathrm{OECD} \mathrm{DAC}$ 은 $\mathrm{ODA}$ 현대화 논의를 통해 크게 4 가지 분류의 새로운 금융수단을 공식 통 계측정 수단으로 도입하고 이를 DAC 통계지침에 반영 완료하였다. 이에 따라 2016년에 보고되 는 2015년 사업실적부터 변경된 기준으로 통계보고가 시작되었다.

OECD는 2016년에 신규 승인된 통계지침(OECD, 2016c; OECD, 2016d)에서 신규 도입된 금 융수단별 상세 정의 및 설명을 제공하고 있는데, 이를 자세히 살펴보면 다음과 같다. 먼저, 상환 조건증여(reimbursable grant)는 채무수단의 한 종류로 수원국 기관에 투자목적으로 제공된 자 금이다. 제공시 특정된 조건에 따라 장기상환을 하는 자금으로, 공여기관은 투자의 전체 또는 일 부의 실패위험성을 가정하며, 투자금 회수의 조건이나 시점 또한 정할 수 있는 수단이다. 상환조 건증여에서 투자 목적으로 중개기관에 제공한 공여국의 자금은 (원금, 이자, 배당금 및 기타 투자 상환금) 공여국에 재투자되거나 반환될 수 있다. 공여국 투자기금을 집행하는 기관은 재정상의 위 험을 일체 부담지지 않으며 (해당기관은 지분 또는 차관투자가 실패하는 경우에도 재정상의 책임 을 지지 않으며, 공여국이 1차 손실을 감수) 동시에 투자에 따른 재정상의 혜택도 얻지 않는다. 공여국은 일정 기간 동안 기금을 제공하며, 만기 시 신탁기금의 투자금액을 회수하거나 중개기관 으로 하여금 기타 투자 또는 자문 목적으로 해당 기금을 사용하도록 하는 방식으로 자금을 지원 하는 금융수단이다(OECD, 2016d)

채무증권의 한 종류인 자산담보증권(Asset-Backed Securities, ABS)은 채권 및 부동산 등 모든 자산을 담보로 발행되는 증권이다. '자산 유동화'2)라는 과정을 통해 개별 매도가 불가능하거 나 쉽지 않은 소규모, 비유동 자산의 집합을 소유하고 있는 자산보유자 (수원국 또는 민간기업)가 기존 은행 차관 또는 채권 금융에 비해 적은 비용으로 기금을 조성할 수 있게 한다.3) 자산담보증 권은 금융시장 접근성이 제한적인 개도국 민간 기업을 대상으로 자산유동화 과정을 통해 대차대 조표를 완화하여 신규 대출을 촉진함으로써 민간기업의 투자역량 활성화에 기여하고, 자산유동화 증권으로 조달한 민간투자 금액을 추적할 방식을 찾을 수 있게 한다는 장점이 있다(OECD, 2016d).

메자닌 금융수단에서는 (1) 메자닌 금융(mezzanine finance), (2) 후순위 차관 (subordinated

2) 자산의 본래 소유자인 '자산보유자'(즉, 기업 또는 신탁 관리자)는 자산을 유동화하고자 해당 자산 매입을 주 기능으로 하 는 '특수목적기구'(SPV)에 매도한다. 특수목적기구는 자산담보증권(ABS)의 형태로 증권을 발행, 판매하며 판매 수익금으로 기초자산을 만들거나 발행한 은행에 상환한다. 자산은 신용평가기관이 자산보유자/매도자에 대하여 부여한 신용등급과는 별도로 평가를 받는다. 경우에 따라 투자자는 담보자를 상대로 청구권을 소유하기도 한다. 특수목적기구는 위험선호도와 투자자의 기타 요구(예: 선순위부터 후순위까지 각기 다른 종류의 증권)에 맞추어 기초자산을 특정 자산집합으로 묶고 (bundling)' 기초자산의 성과를 기준으로 수익을 분배해야 할 책임이 있다. 상세내용 OECD, 2016d 참조.

3) 자산유동화 없이는 자산보유자가 자체 신용을 담보로 대출을 받아 자금을 조달해야 하는데, 자산보유자의 신용등급보다 유동화 된 자산집합의 수취채권의 신용등급이 더 높은 경우가 일반적이다. 
(junior) loan), (3) 우선주(preferred equity)를 도입하고, 정의를 설명하고 있다. 혼합 (하이브 리드) 금융으로도 불리는 메자닌 금융은 '선순위부채(senior debt)'와 '자본(equity)' 사이에 존재 하는 모든 금융상품을 의미한다. 청구권이 선순위채(senior lender)보다는 후순위이나, 지분투자 자(equity investors)보다는 우선하는 권리 보유한다. 따라서 일반적으로 기대수익은 전통적인 대출이자보다는 높으나, 지분투자자(equity investor)보다는 낮다. 후순위차관(subordinated loan)은 원리금 상환 및 담보권 실행 시 변제 순위가 통상의 대출보다 낮은 차관이며, 우선주는 디폴트 (채무불이행) 시, 모든 선순위권리 및 후순위차관의 변제 이후 변제가 이뤼지나, 다른 주 식보다는 우선하는 권리 보유하는 주식이다. 위험부담이 더 커진 만큼 다른 주주들 보다 우선하 여 배당하게 된다(OECD, 2016d).

지분투자 및 집합투자기구(Equity and Shares in Collective Investment Vehicles, 이하 $\mathrm{CIV})$ 에서 공공 투자자는 기업 소유권의 지분을 매입하는 방식으로 해당 기업의 지분을 직접 확보 하거나, 주식 또는 채권펀드(debt fund)에 투자하는 방식으로 해당 기업에 간접적으로 차관을 제 공할 수 있다. 보통주(common equity)는 이익배당이나 잔여재산 분배 등의 재산적 내용에 관하 여 다른 여러 종류의 주식들의 우선적 지위 또는 후배적 지위를 결정하는 기준이 되는 주식으로 서 이익배당이나 잔여재산분배에 있어 어떠한 제한이나 우선권도 주어지지 않는 주식이다. 투자 가 실패할 경우 최종위험을 부담하고 성공할 경우 이득을 받는 잔여지분의 성격을 갖는데, 자산 에 대한 청구권은 부채를 먼저 변제하고 그 다음 우선주에 대한 배분이 이루어지고 난 후, 남은 잔 여지분(잔존가치)이 모두 보통주에 귀속되게 된다(OECD, 2016c). 한편, CIV는 다른 투자자들의 자금과 함께 공동으로 이뤄지는 투자지분 (투자대상은 금용 또는 비금융자산 모두 포함)을 일컫는 다. 4) 채무자의 채무불이행 시, 변제 받는 순위가 다른 다양한 선/후순위의 지분/증권이 존재할 수 있으나, DAC 통계목적상 1차 손실 지분/증권(first-loss shares/units)만을 주식으로 보고하 며, 나머지 모든 유형의 선순위 지분은 메자닌 금융으로 간주한다. 또한 DAC 통계에서, 투자자 의 금융 노력은 주식/지분/수익증권을 매입한 시점에 측정한다. 한편 주식/지분/수익증권의 매각 은 개도국에서 투자자에게로 자금이 다시 반환되었음을 의미하므로 마이너스(-) 자금흐름으로 기 록하며, 배당금은 기록하지 않는다(OECD, 2016d). 집합투자기구를 통한 투자는 투자를 받는 수 원국(기업) 입장에서는 개별 투자자를 확보하는 것보다 거래 비용 측면에서 더 용이하면서 부담이 적다는 장점이 있다.

보증/보험(guarantees/insurance)은 대출이나 주식투자의 채무불이행 또는 투자실패 발생 시 보증금액을 대신하여 이행할 것을 담보하는 제도이다.

4) 집합투자기금은 기업구조를 사용하는 경우 지분을, 신탁구조를 사용하는 경우 수익증권을 발행한다(OECD, 2016d). 


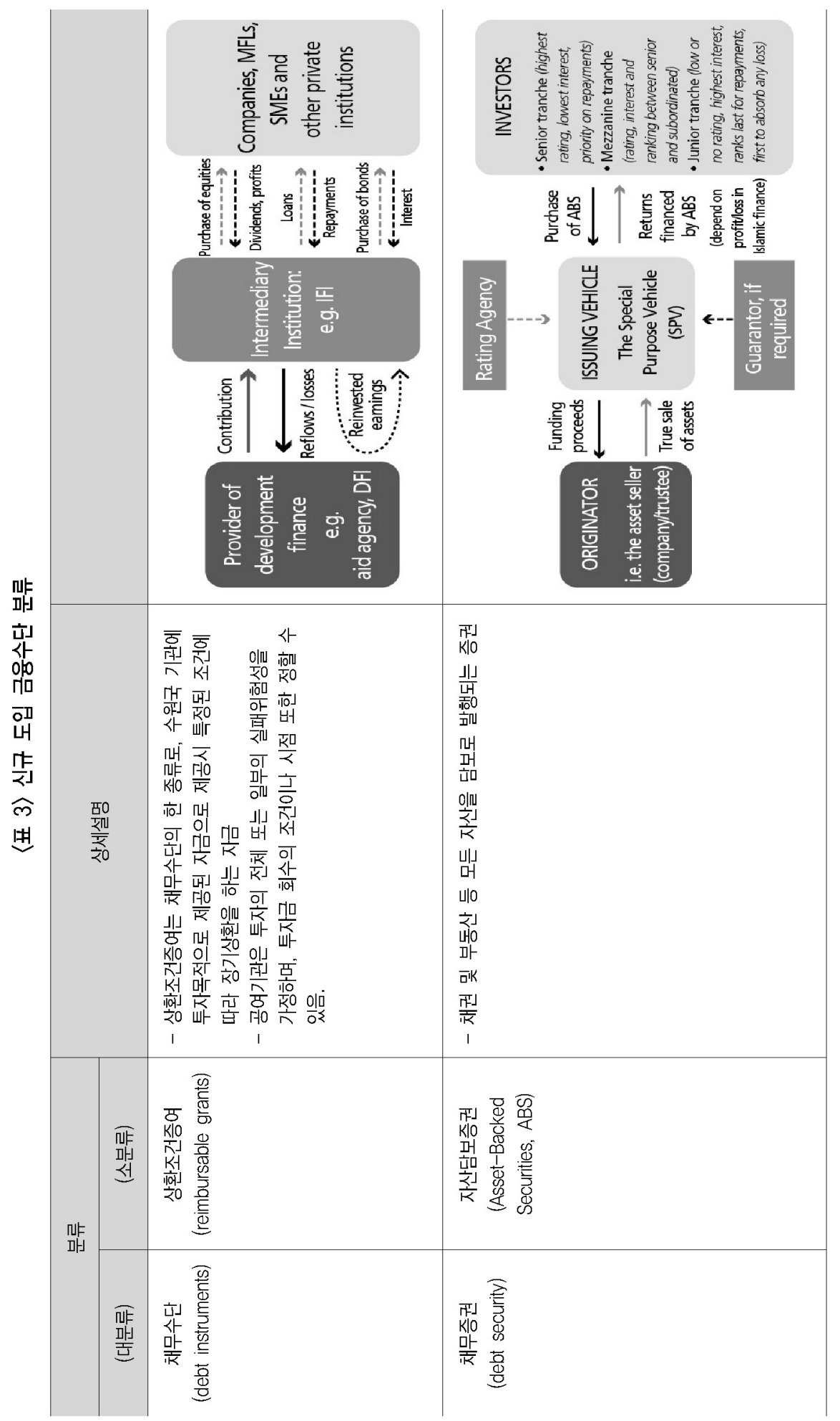

제 I 장

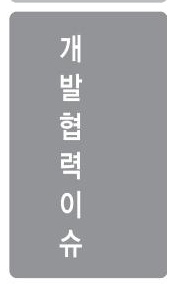

제 II 장

제 표장 


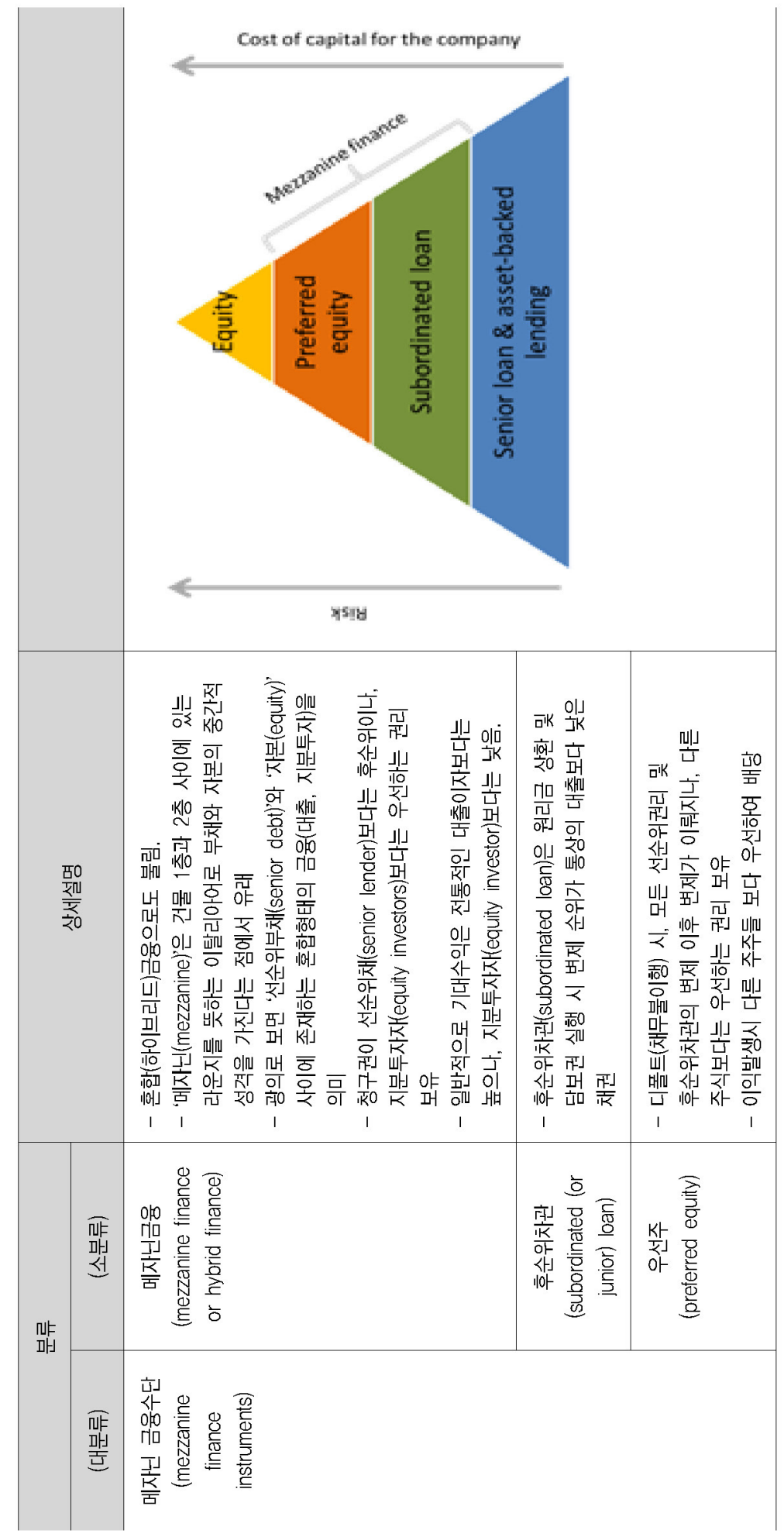




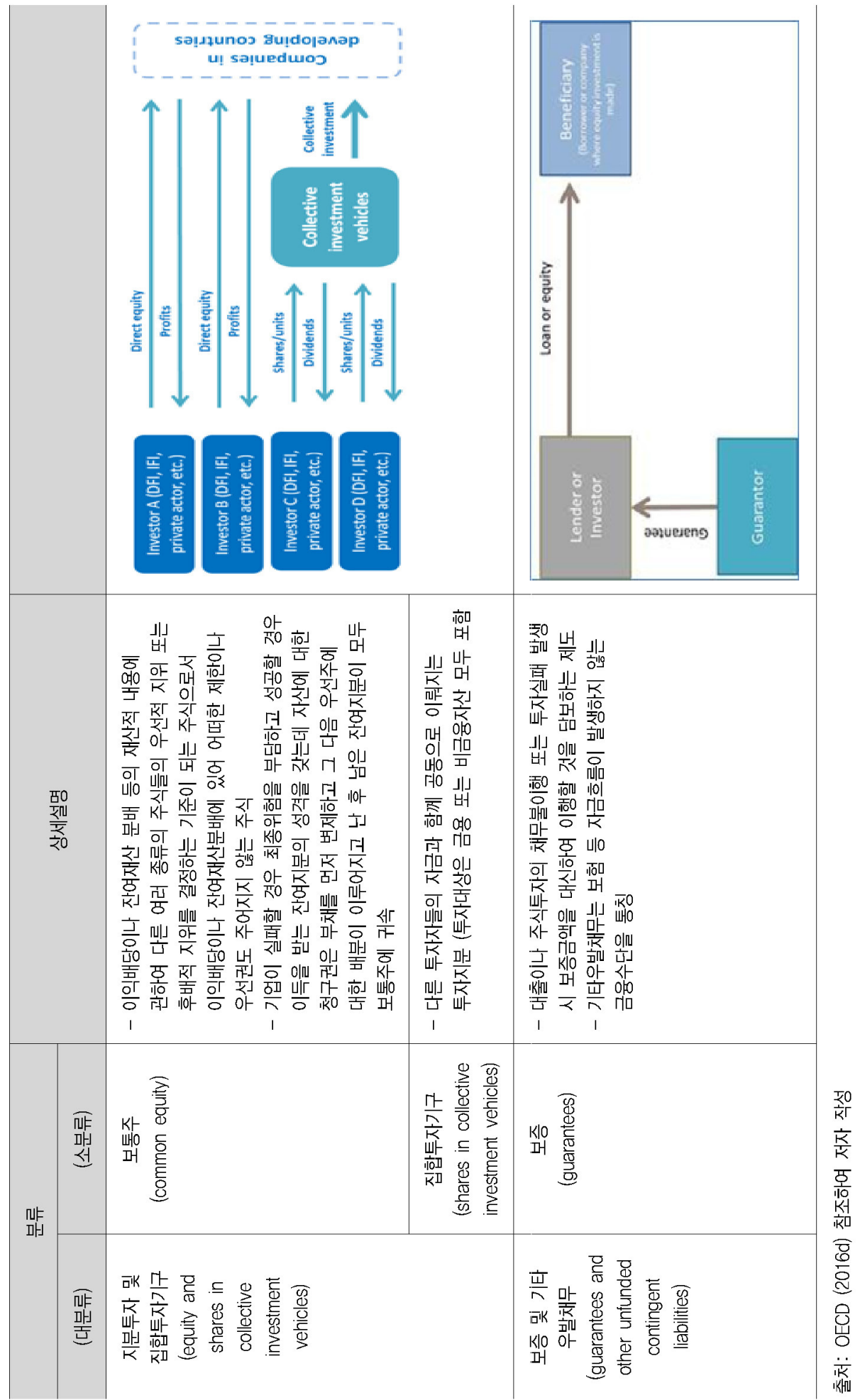

제 I 장

개
발
협
력
이
슈

제 II 장

제 III 장 


\section{3. 공적지원으로 인해 동원된 민간재원 측정}

$\mathrm{OECD} \mathrm{DAC}$ 은 공적자금으로 인해 동원된 민간재원을 측정하는 것에도 합의하였다. 이에 따라 2016년 HLM에서 통계지침 수정안 승인 시 신디케이트론(syndicated loans), 보증(guarantees), 집합투자기구(shares in collective investment vehicle)의 세 가지 방식의 지원으로 동원된 민 간재원을 측정하여 보고하는 방법론이 마련되었다. 추후 다른 금융수단에 대한 동원효과 측정방 식은 추가 논의하기로 결정되었다. 구체적인 보고 시기는 2016년 실적부터 OECD DAC의 공식 통계에 보고될 예정이다.

각 금융수단별 동원 조달 금액을 표기하는 방식은 통계지침 수정안(OECD, 2016d)에 상세 기 술되어 있다. 먼저, 신디케이트론은 주선기관(arranger)이 공공기관이 경우, 공공부문이 주선기 관 또는 참여기관으로 개입하지 않았다면 민간투자자가 차관을 제공하지 않았을 것이라는 암묵적 인 가정이 성립하는 경우, 조달된 금액의 $50 \%$ 는 공공 주선기관(arranger)의 기여분으로 보고하 고, 잔여분(50\%)은 참여기관의 기여분으로 보고하며, 공적지원에 대한 해당 차관제공자의 금액 비중에 따라 비례 배분한다. 단, 주선기관이 민간인 경우에는 공공기관의 참여가 없었다면 민간투 자자(주선기관 포함)가 투자하지 않았을 것이라는 가정 하에, 조달 금액의 $100 \%$ 가 공적 참여기관 의 기여분으로 기록된다.

$\mathrm{CIV}$ 를 통해 조달한 금액은 최대 5 년의 기금 조성 기간 동안 약정된 민간투자 총액을 의미하 며, 해당 금액은 고위험 트란쉐(tranche)에 투자한 공공기관의 기여분으로 기록된다. 다시 말해, 일반 집합투자기구 내의 보통주나 1차 손실 주식 또는 구조화 CIV 내의 고위험 트란쉐 지분에 투자한 경우이다. 다수의 공공기관이 이 같은 트란쉐에 투자한 경우, 조달한 금액을 공공기관별로 비례 배분한다. 따라서 조달금액 계산 시에는 집합투자기구에 참여한 공공투자기관의 수를 고려 한다. 조달된 금액의 $50 \%$ 는 집합투자기구의 고위험 트란쉐에 투자한 공공기관에 동일한 기여분 으로 기록하며, 잔여분 50\%는 민간투자가 이루어진 시점에 집합투자기구의 고위험 트란쉐에 대 한 각 공공기관의 자금 비중에 따라 비례 배분한다(OECD, 2016d).

보증의 경우 공적 보증 없이는 민간투자자가 차관을 제공하지 않았을 것이라는 가정이 성립, 따라서 공공보증기관이 자금조달에 기여했다고 볼 수 있는 경우에 민간재원 동원액을 보고할 수 있다. 공동 보증의 경우, 조달된 금액은 각 보증기관이 보증한 금액만큼 비례 배분하여 보고한다 (OECD, 2016c).

한편 $\mathrm{OECD} \mathrm{DAC은} \mathrm{2017년} \mathrm{실시될} \mathrm{공식보고} \mathrm{이전에} \mathrm{공적지원으로} \mathrm{인해} \mathrm{동원된} \mathrm{민간재원의}$ 현황을 파악하기 위해 DAC Survey를 2015년부터 실시하였는데, 2016년 실시된 2차 조사에서 는 기합의 되었던 3 개의 금융 수단 이외에 2 가지 금융수단 (직접투자(direct investment)와 전대 금융(credit line))을 추가하여 조사를 실시한 바 있다(OECD, 2016f). 


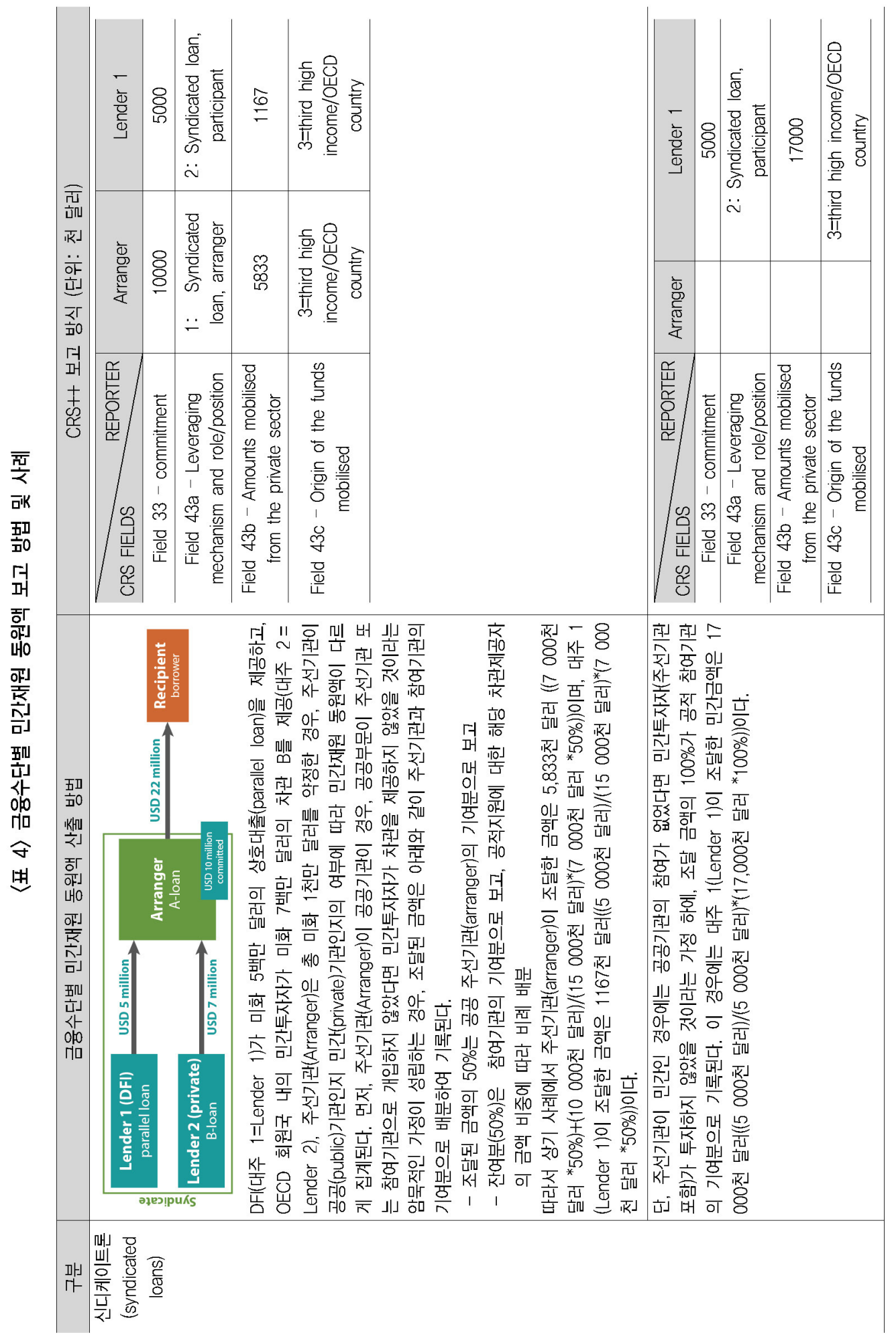

\begin{tabular}{|l}
\hline 개 \\
발 \\
협 \\
력 \\
이 \\
슈 \\
\hline 제 II 장 \\
\hline 제 III 장
\end{tabular}




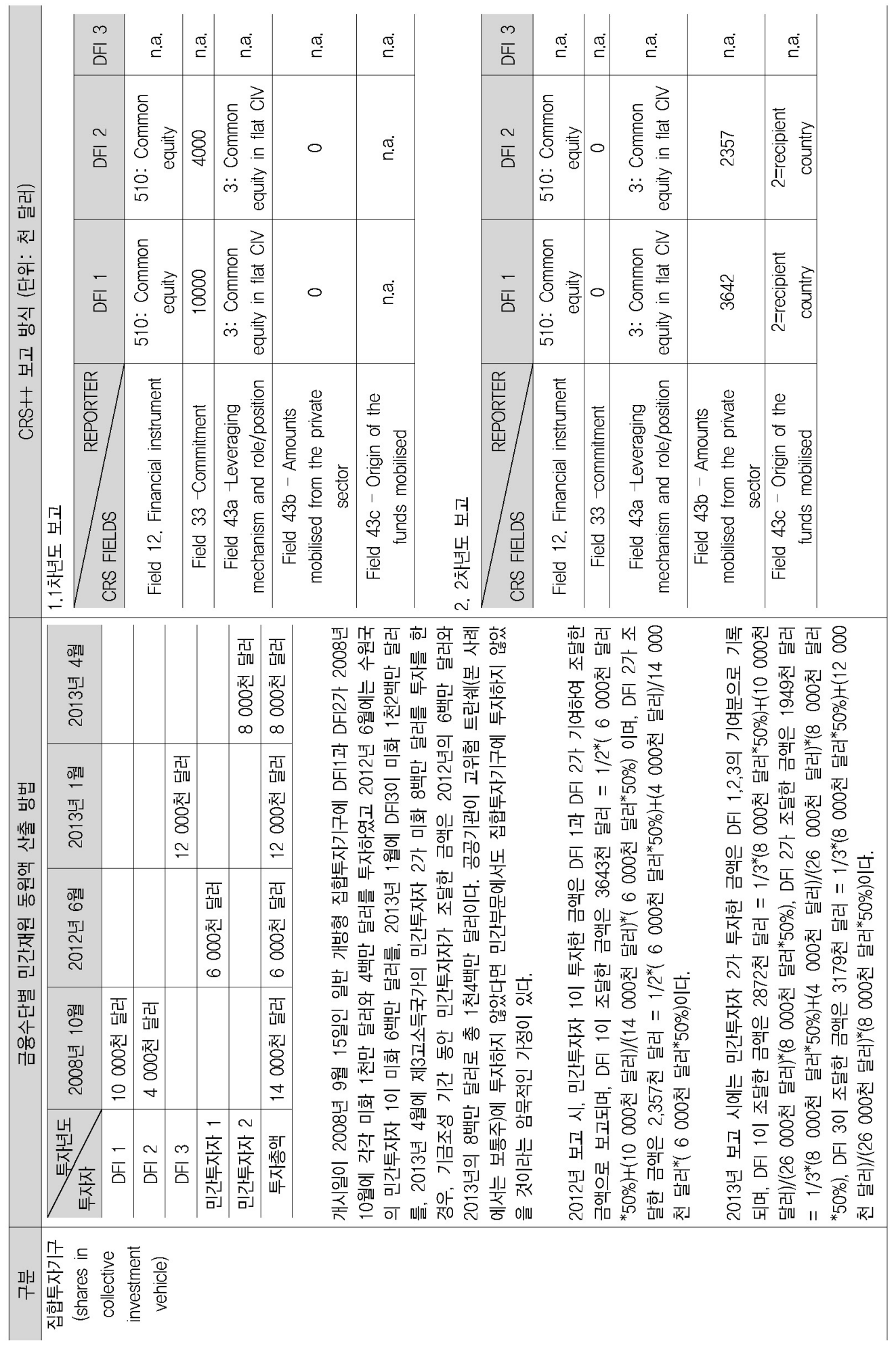




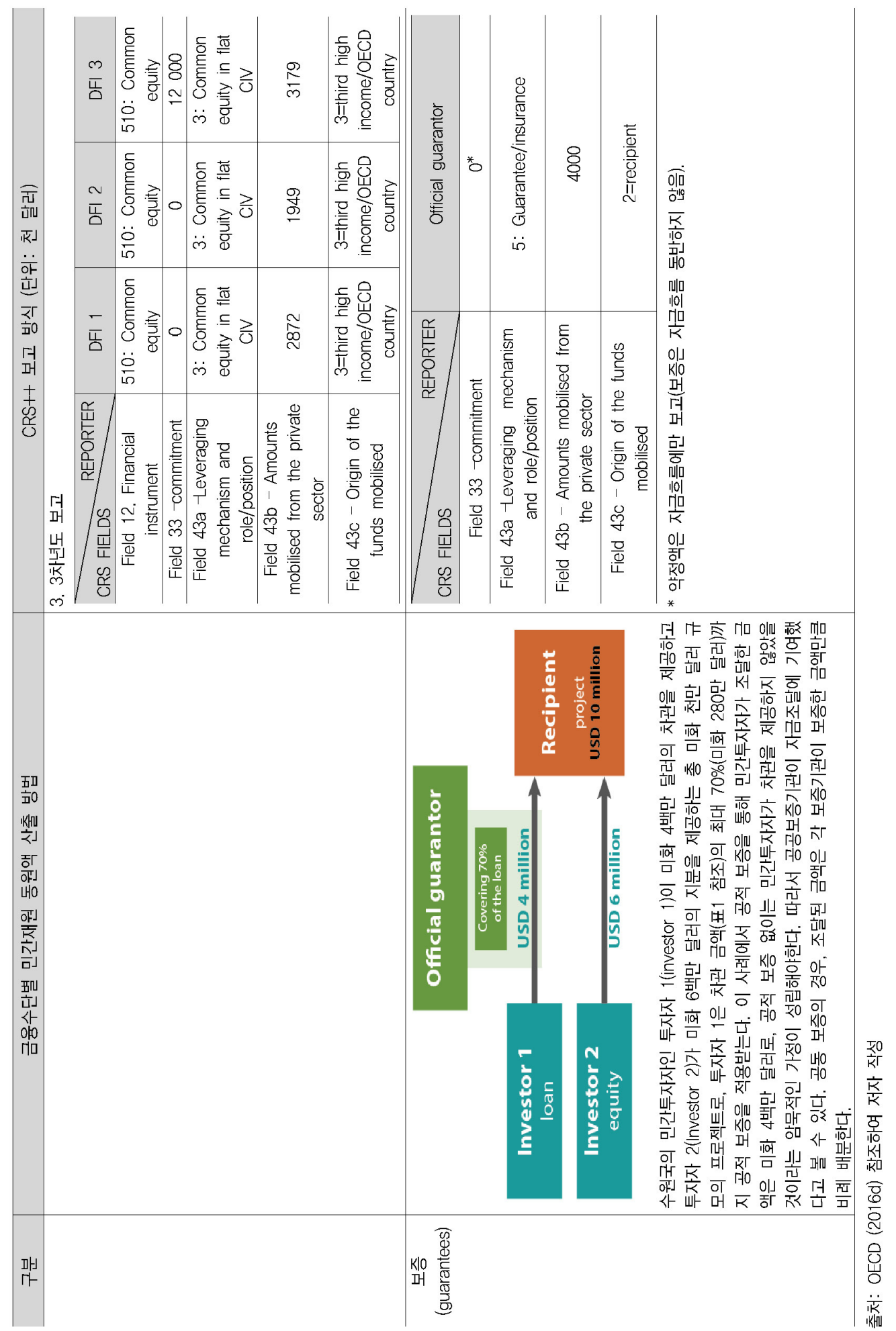

\section{제 I 장}

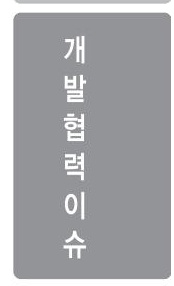

제 II 장

제 III 장 


\section{4. 민간금융수단(Private-Sector Instruments)의 측정}

민간금융수단(private-Sector instruments)은 일반적으로 차관, 보증, 메자닌금융(mezzanine finance), 지분투자(equity) 등을 사용하여 민간에게 제공되는 자금을 의미한다. 민간금융수단과 시장유사수단 (market-like financial instruments)이 혼용되어 사용되고 있으나,5) OECD 사 무국은 민간금융수단은 개도국 기업에게 제공된 재원만을 의미하는 단어이며, 시장유사수단은 개 도국 민간과 공공분야를 모두 포괄하여 지원이 이뤄진 재원을 의미하는 개념이라고 차이를 밝힌 바 있었다(OECD, 2014a). 그러나 이후에도 OECD DAC 및 회원국 사이에서 두 개념이 혼재되 어 사용되어 왔음을 고려하여, $\mathrm{OECD}$ 에서도 $\mathrm{PSI}$ 의 정의를 민간 또는 공공에게 증여와 차관을 제 외한 다른 금융수단을 활용하여 제공하는 자금을 일컫는 표현으로 사용하고 있으며, 이는 2016년 DAC HLM 코뮤니케에서도 확인된 바 있다(OECD, 2014b; OECD, 2016a).

〈그림 1〉양자개발협력에서 PSI 범위

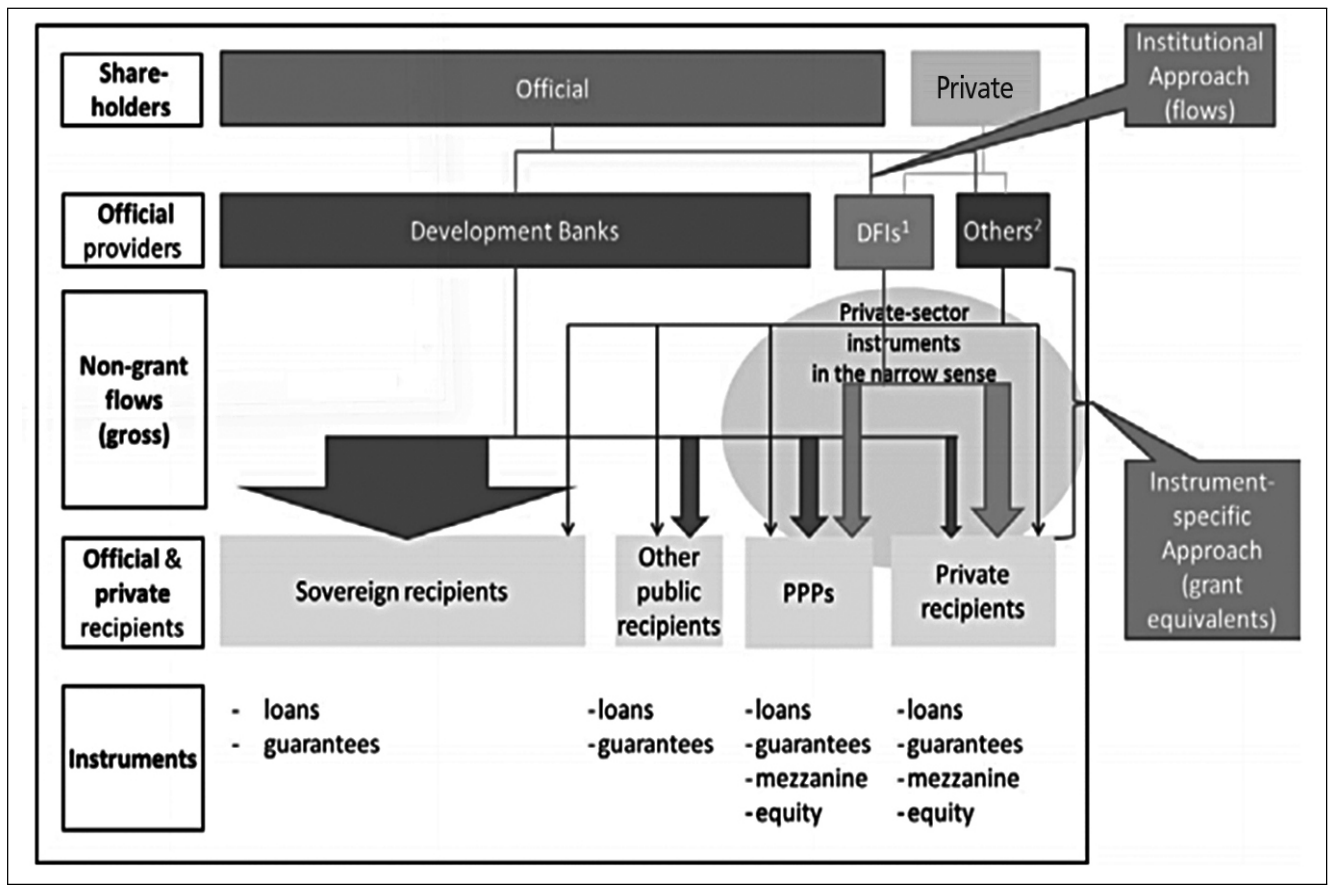

출처: OECD (2014b)

5) 상세내용 박수영·조한슬 (2015) 참조 
이러한 PSI를 ODA로 측정하고자 하는 논의의 시작은 2011년으로 거슬러 올라간다. 2011년 에는 개발재원으로서 비(非)ODA자금흐름(non-ODA flows)을 측정할 필요성이 제기됨으로서 논 의가 시작되었고, 2012년 HLM에서 공여국의 노력을 포함한 외부개발재원을 측정하는 방안을 마 련하기로 제안됨에 따라 논의가 촉발되게 된다. 2012년 당시 영국이 DFI를 통한 민간재원의 개 도국 내 유입을 $\mathrm{ODA}$ 로 측정할 필요성, 측정방법에 대한 보고서를 통계작업반에 제출하고, ${ }^{6)}$ 이 를 바탕으로 논의가 계속 진행되었다, 2014 년 ODA 현대화 작업을 시작으로 동 논의가 본격적으 로 시작된 이후, PSI 논의는 측정방식(수단별, 기관별 측정방식), 각 방식별 측정방안 등 다양한 이슈로 인해 논의가 더디게 개진되었으나, 2016년 HLM에서 PSI의 측정에 관한 기본원칙에 합 의하게 되었다(상세사항은 〈상자 1〉 참조).

$\mathrm{PSI}$ 의 도입 및 측정과 관련한 주요 결정사항 및 이슈는 다음과 같다. 민간금융수단의 제공 노 력을 $\mathrm{ODA}$ 로 인정하는 반면, 현금흐름 자체는 TOSSD로 보고하며, 각 기관별로 ODA 보고 시 기 관중심 접근방식과 수단중심 접근방식 중 선택하여 보고가 가능하게 결정되었다. 다만, 측정방식 의 변경은 원칙적으로는 가능하나, ODA의 신뢰성 및 비교가능성을 위해 전환유예기간(lock-in period) 도입에 관한 논의를 계속하기로 합의하였다. 이 밖에도 두 가지 방식 하에 정부에 상환 되는 자본 수익과 배당 수익은 (-)ODA로 계산하고, 2 년간의 시범운영 검토 결과를 토대로 개선 사항을 고려하는 방향에 원칙적으로 합의하였다(OECD, 2016a).

$\mathrm{ODA}$ 적합성 평가는 공통 양식을 사용하여 모든 양자 $\mathrm{DFI}$ 와 (요청 시) 기타 기관들을 대상으 로 실시하기로 합의하였으며, 평가는 DFI의 설립목적, 사업 포트폴리오, 투자 전략 및 due diligence 메커니즘의 조사에 기반하여 실시하기로 합의하였다. 단, 모든 회원국은 측정방식과 관 계없이 PSI의 ODA 보고에 있어 사업 수준에서의 개발 목적 및 추가성에 관한 정보를 CRS에 제 공하고, 평가 받을 예정이다.7)

기관별 측정방식을 선택할 경우, 기관별 ODA 인정계수(ODA coefficient)를 산출하여, 해당 비율만큼의 출자액을 현금흐름 기준으로 보고하고 상환액(reflow)은 (-)로 보고하게 된다. 한편, 각 금융수단 별 $\mathrm{ODA}$ 계산방식은 다음과 같다. 먼저 증여에 의한 기여는 명목가치로 $\mathrm{ODA}$ 로 계 산하며, 상환조건증여는 여러 유형의 계약 및 초기 투자 파일을 포함하는 하이브리드 부채수단으 로, 상환액(reflow)과 위험 측정이 가능한 정보가 충분히 확보된 경우, 증여등가액 방식으로 측정 하며 그렇지 않은 경우에는 사후측정을 적용한다. 대출은 증여등가액 방식을 따르며, 할인율은

6) 상세 내용 $\mathrm{OECD}, 2012 \mathrm{a}$ 참조.

7) $\mathrm{OECD} \mathrm{DAC은} \mathrm{지난} \mathrm{3월} \mathrm{통계작업반에서} \mathrm{ODA} \mathrm{적격성} \mathrm{평가양식(template)} \mathrm{중} \mathrm{기관} \mathrm{설립목적} \mathrm{및} \mathrm{역할(mandate/mission),}$ 포트폴리오 및 지원규모(project portfolio/volume of operation), 투자전략 등에 대한 서면의견 제출사항을 반영하여 수정 안을 제시하였고, $\mathrm{PSI}$ 가 ODA로 인정되기 위한 '추가성(additionality) 정의를 재무적 추가성(financial additionality) 및 가 치 추가성(value additionality)으로 확대하는 것에 잠정 합의하였다. 


\section{〈상자 1〉 $2016 \mathrm{HLM}$ 민간금융수단의 ODA 현대화 기본원칙}

\begin{tabular}{|c|c|}
\hline A. 기본원칙 & 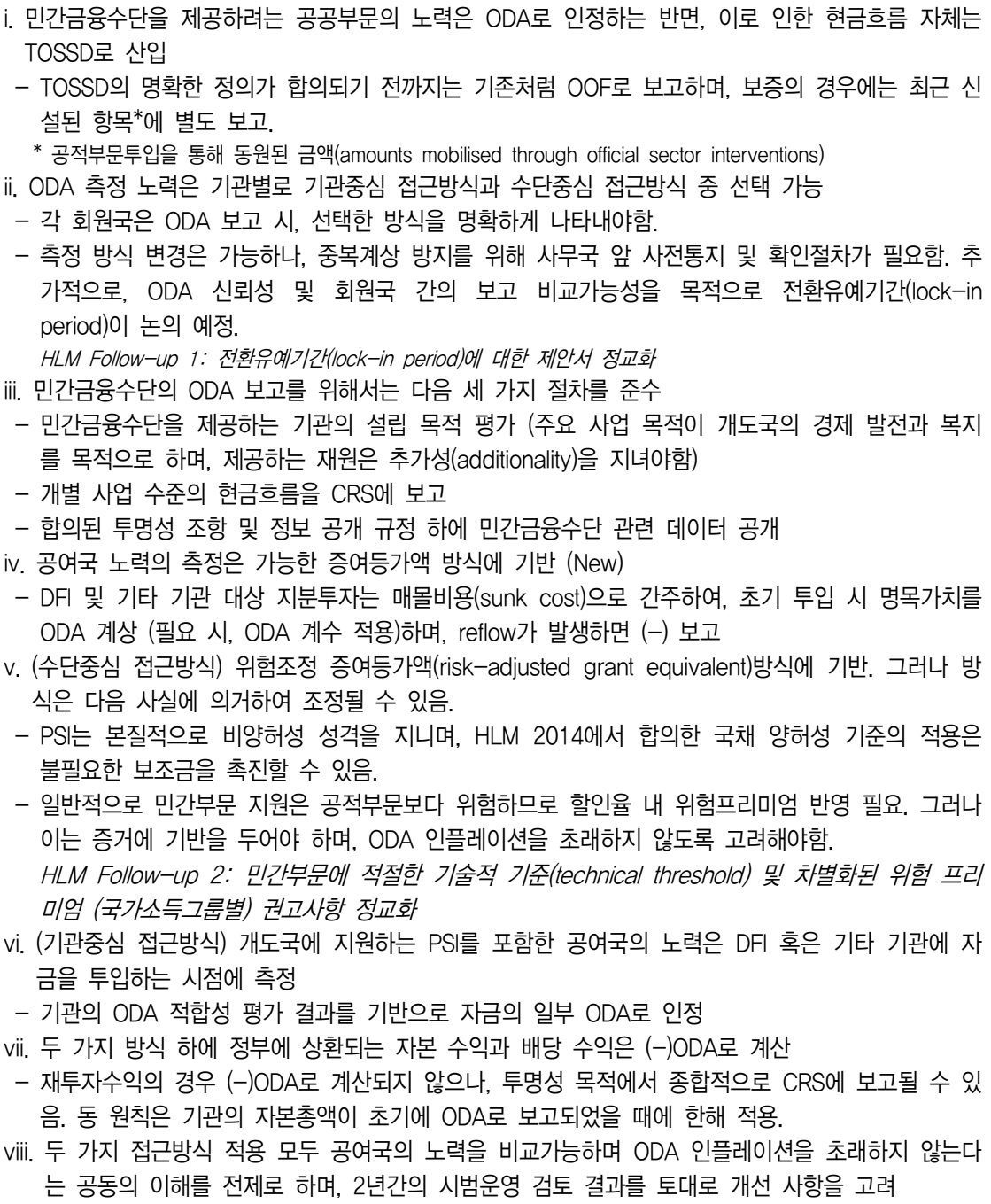 \\
\hline & $\begin{array}{l}\text { ix. ODA 적합성 평가는 공통 양식을 사용하여 모든 양자 DFl와 (요청 시) 기타 기관들을 대상으로 실시 } \\
\text { HLM Follow-up 3: 양식 제안서 정교화 } \\
\text { x. 평가는 DFI의 설립목적, 사업 포트폴리오, 투자 전략 및 due diligence 메커니즘의 조사에 기반 } \\
\text { - ODA 대상국가의 지원 할당량, 주요목적이 개도국 경제개발과 복지 증진이 고려됨. 비ODA대상국 } \\
\text { 가 및 사업영역에서 환발한 활동을 하는 경우, ODA 계수 산정을 위해 전체 포트폴리오 내 ODA } \\
\text { 적합 활동의 비중을 측정 } \\
\text { - 기관의 투자전략 및 due diligence 메커니즘 관련 정보는 재원의 추가성 평가 } \\
\text { HLM Follow-up } 4: \text { 측정 기준을 위한 제안서 개발 } \\
\text { xi. 모든 회원국은 PSSI의 ODA 보고에 있어 사업 수준에서의 개발 목적 및 추가성에 관한 정보를 } \\
\text { CRS에 제공 } \\
\text { - 측정방식과 관계없이 합의된 기본원칙에 의해 보고된 정보 준수는 동료검토 및 PSI 관련 정기보 } \\
\text { 고서(2년 } 1 \text { 회)에 의해 DAC에 의해 펵가 } \\
\text { HLM Follow-up 5: 추가성의 정의 관련 작업; CRS에 추가성 보고를 위한 drop-down 메뉴 정교화 }\end{array}$ \\
\hline
\end{tabular}




\begin{tabular}{|c|c|c|}
\hline $\begin{array}{l}\text { C. ODA } \\
\text { 계산 방식 }\end{array}$ & \multicolumn{2}{|c|}{ 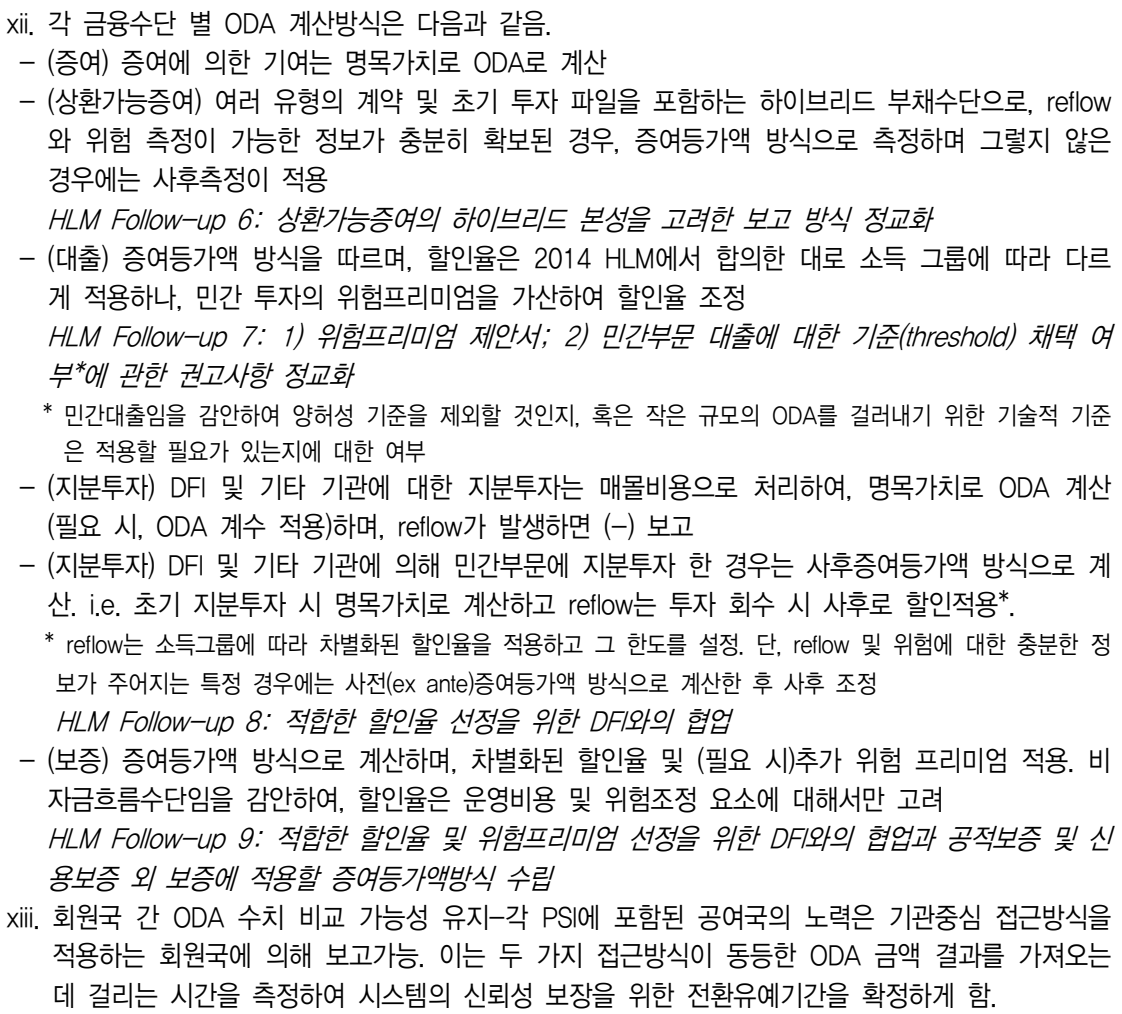 } \\
\hline \multirow{4}{*}{$\begin{array}{l}\text { D. 투명성 } \\
\text { 조항 및 } \\
\text { 정보공개 } \\
\text { 규정 }\end{array}$} & \multicolumn{2}{|c|}{$\begin{array}{l}\text { xiv. PSI의 ODA 보고는 구체적인 투명성 조항 및 정보공개 규정에 의거하며, 주요 원칙은 다음 표와 } \\
\text { 같음. }\end{array}$} \\
\hline & 보고 요건 (reporting requirements) & 정보 공개 (data disclosure) \\
\hline & $\begin{array}{l}\text { - 정보는 모든 공여국에 의해 가능한 동일 } \\
\text { 기준으로 보고 } \\
\text { - PSI 흐름은 CRS에서 사업수준으로 보고 } \\
\text { (금융조건 포함) } \\
\text { - DFI에 투입된 자금흐름 관련 정보는 모 } \\
\text { 든 회원국으로부터 수집 (해당 요소는 } \\
\text { 수단중심을 선택한 국가 대상 분석 목적 } \\
\text { 용으로 사용) } \\
\text { - 자본수익 및 배당금은 총금액으로 보고 }\end{array}$ & $\begin{array}{l}\text { - 공여국의 노력 측정은 접근방식과 관계없이 } \\
\text { 사업 수준에서 공개된 정보에 대해 동일한 정 } \\
\text { 보 규칙 적용 } \\
\text { - 사업수준에서 PSI 흐름을 공개하되, 고객 관 } \\
\text { 련 기밀 의무 준수 (고객명, 금융조건) } \\
\text { - 수단중심 접근방식의 경우, DFI와의 자본흐 } \\
\text { 름 정보는 정기적 DAC 통계에 나타나지 않 } \\
\text { 음. (그러나, 사무국의 분석 목적으로 수집되 } \\
\text { 며 PSI 격년간 보고의 일부로 활용) }\end{array}$ \\
\hline & \multicolumn{2}{|c|}{ HLM Follow-up 10: 보고 요건 및 정보 공개 관련 규칙 구체화를 위한 DFI와의 협업 } \\
\hline & \multicolumn{2}{|c|}{$\begin{array}{l}\text { xiii. ODA 보고의 신뢰성 확보를 위해 DAC에 의한 세이프가드 정기적 모니터링에 의거함. DAC 혹은 } \\
\text { DACOㅣ 지정한 조직에 의해 PSI의 질적/양적 측면을 포함하는 정기적 보고를 격년 실시 } \\
\text { - 동 보고서는 DFIs financing의 추가성에 대한 증거 확보, 시장왜곡 및 민간금융 구축효과 방지를 } \\
\text { 분석 예정. 첫 번째 보고서에 기반을 두어 DAC는 PSI를 위한 최소 기준 및 규칙 수립 여부를 고 } \\
\text { 려할 예정. } \\
\text { HLM Follow-up } 11: \text { PS/ 모니터링 목적의 세이프가드 및 규범 관련 제안서 수립 }\end{array}$} \\
\hline
\end{tabular}

출처: OECD (2016a) 참조하여 오수현 ·조한슬 작성 
2014 HLM에서 합의한 대로 소득 그룹에 따라 다르게 적용하나, 민간 투자의 위험프리미엄을 가 산하여 할인율 조정하기로 하였다. DFI 및 기타 기관에 대한 지분투자는 매몰비용으로 처리하여, 명목가치로 $\mathrm{ODA}$ 계산 (필요 시, ODA 계수 적용)하며, 상환액(reflow)이 발생하면 (-) 보고하 고, DFI 및 기타 기관에 의해 민간부문에 지분투자 한 경우는 초기 지분투자 시 명목가치로 계산 하고 reflow는 투자 회수 시 사후로 할인 적용하여 다시 보고하는 방식의 사후증여등가액 방식으 로 계산하기로 하였다. 끝으로 보증은 증여등가액 방식으로 계산하며, 차별화된 할인율 및 (필요 시) 추가 위험 프리미엄 적용하되, 비자금흐름수단임을 감안하여, 할인율은 운영비용 및 위험조정 요소에 대해서만 고려하기로 결정하였다(OECD, 2016a).

$\mathrm{PSI}$ 의 $\mathrm{ODA}$ 보고는 구체적인 투명성 조항 및 정보공개 규정에 의거하며, 정보는 모든 공여국 에 의해 가능한 동일 기준으로 보고하기로 하였으며, 공여국의 노력 측정은 접근방식과 관계없이 사업 수준에서 공개된 정보에 대해 동일한 정보 규칙 적용하기로 하였다. 구체적으로 PSI 흐름은 $\mathrm{CRS}$ 에서 금융조건을 포함한 사업수준으로 보고하고, DFI에 투입된 자금흐름 관련 정보는 모든 회원국으로부터 수집 (해당 요소는 수단중심을 선택한 국가 대상 분석 목적용으로 사용), 자본수 익 및 배당금은 총금액으로 보고하기로 하였다. 또한 사업수준에서 PSI 흐름을 공개하되, 고객 관련 기밀 의무 준수 (고객명, 금융조건)하고, 수단중심 접근방식의 경우, DFI와의 자본흐름 정보 는 정기적 $\mathrm{DAC}$ 통계에 나타나지 않으나, 사무국의 분석 목적으로 수집되며 PSI 격년간 보고의 일부로 활용하기로 결정하였다. 끝으로 $\mathrm{ODA}$ 보고의 신뢰성 확보를 위해 $\mathrm{DAC}$ 에 의한 세이프가 드 정기적 모니터링을 실시하기로 결정하였으며, $\mathrm{DAC}$ 혹은 $\mathrm{DAC}$ 이 지정한 조직에 의해 PSI의 질적/양적 측면을 포함하는 정기적 보고를 격년 실시키로 하였다(OECD, 2016a).

현재 동 기본원칙에 근거한 세부 측정방안 등을 협의하는 과정에 있으나, 할인율, 추가 리스크 프리미엄, ODA적격 최소 양허성 수준 등 여러 이슈에 대해 아직 구체적인 합의가 이뤄지지 않은 상황이다. ${ }^{8)}$

\section{TOSSD의 도입}

TOSSD9)는 개발도상국의 지속가능한 발전을 위해 유입되는 모든 종류의 공적개발재원을 측정 하기 위해 도입이 결정된 새로운 개념·통계로, $\mathrm{ODA}$ 현대화 논의의 한 축을 이루고 있다(〈그림 2〉

8) 지난 2017년 OECD DAC 통계작업반 회의 이후 진행된 논의에서, 위험 프리미엄과 관련하여서는, PSI 차관의 최소 양허 성 기준을 $0 \%$ 로 제안하며, 추가 위험 프리미엄은 모든 국가 및 수단에 대해 $1.5 \%$ 로 동일하게 적용할 것이 제시되었다.

9) TOSSD는 Total Official Support for Sustainable Development의 약자로 일반적으로 총공적개발지원으로 표기한다. TOSSD가 처음 논의가 시작되었을 때는 가운데 'Sustainable'이 빠진 TOSD로 더 많이 표기되어 오다, 최근에는 TOSSD 로 명칭이 변경되어 사용되고 있다. 
참조). ${ }^{10)} \mathrm{TOSSD}$ 로 계상되기 위해서는 공적개발재원이 SDGs 달성을 목표로 하는 동시에 개도국 의 개발목표와 조화를 이루어야 하며, WTO 등 국제규범이나 원칙에 부합하여야 한다. 따라서 $\mathrm{TOSSD}$ 의 지원범위는 지속가능개발의 3 대 분야인 경제성장, 사회통합, 환경지속성을 포괄하고, 더 나아가 개발 선행조건(development enablers)과 공공재 등의 글로벌 도전과제도 지원 분야에 포함된다. 지원 목적 또한 개도국의 경제사회개발의 단일 목적이 아닌 공여주체의 복합적인 지원 동기가 인정되며, 더 나아가 개도국과 공여국의 상호이익을 추구하는 활동도 TOSSD에 포함된다.

〈그림 2〉 TOSSD와 ODA 비교

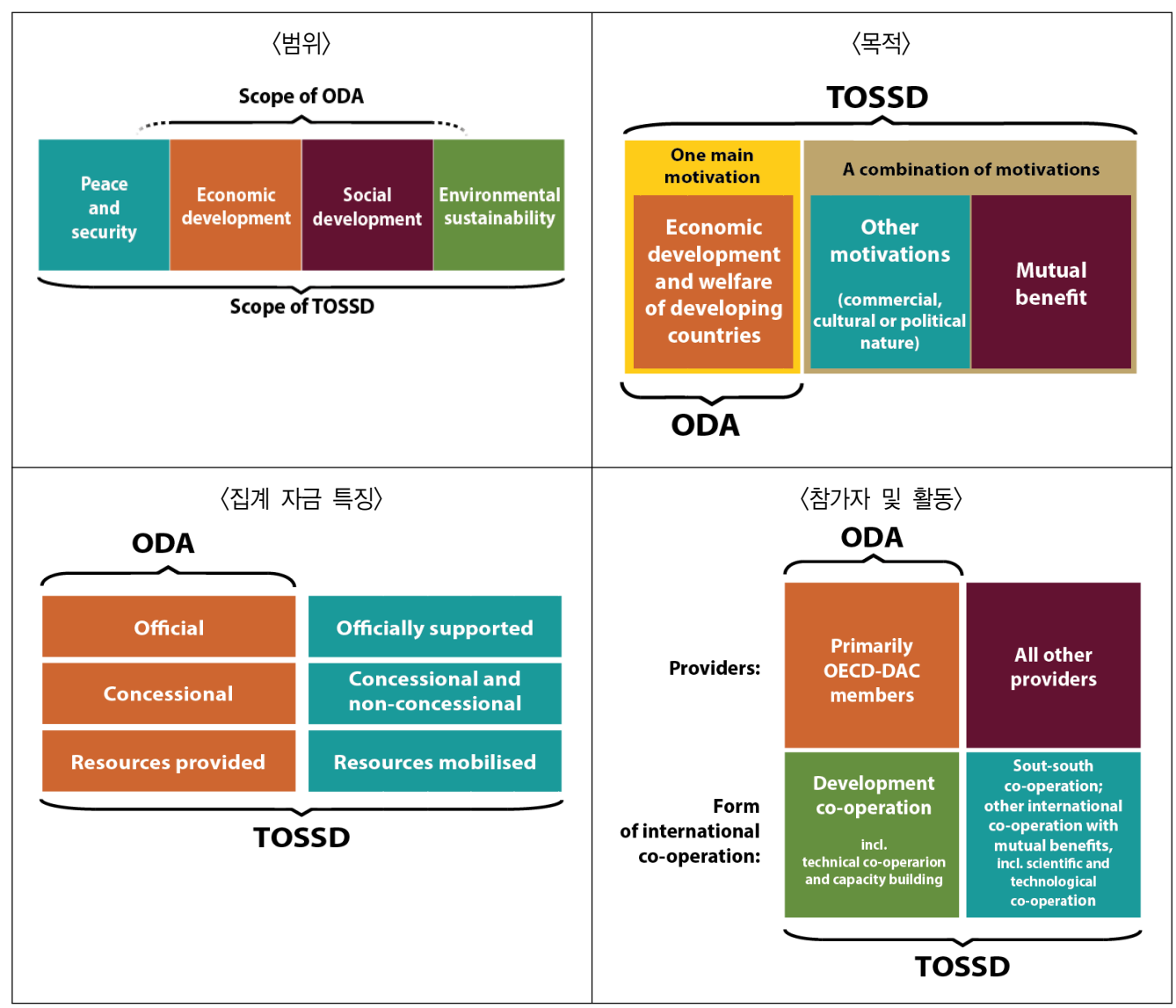

출처: OECD (2016e)

10) ODA 대체하는 것이 아닌 보완적 (complementary)으로 이해되어야 하며 ODA/GNI $0.7 \%$ 공약책무를 회피하는 사유로 활용되어서는 안 됨을 지속적으로 강조하고 있다(OECD, 2014C; OECD, 2016e). 
지원주체 역시 $\mathrm{DAC}$ 회원국이 아닌 모든 공여주체를 포괄하고 있으며, 양허성 수준에 상관없이 모든 개발재원의 흐름을 측정하여, 개발재원을 총체적으로 파악하려고 목표하고 있다. 이에 따라, $\mathrm{TOSSD}$ 는 자금흐름(resource flows)을 기준으로 수집되어 보고될 예정이며, 양자 또는 다자채널 을 통해 수원국으로 유입되는 공적개발재원을 모두 측정할 예정이며, 민간재원 동원액도 표기될 예정이다(OECD, 2016e).

현재 OECD DAC 사무국은 2016년 6월 TOSSD 1차 개요서(compendium)를 발표하고, 의견 수렴과정을 거치고 있으며, 향후 최종안을 수립할 예정이다. 또한 TOSSD의 구체적인 범주와 거 버넌스 구조, 모니터링 방법 등에 대해서도 현재 논의가 진행 중이다. 지난 2016년 HLM에서 합 의사항의 후속조치로 오늘 10월 개최 예정인 OECD SLM 회의에 TOSSD 모니터링을 위한 프레 임 개발을 완료하여 보고할 예정이다.

\section{III. 시사점 및 결론}

\section{1. 민간자금 차입을 통한 $\mathrm{ODA}$ 차관의 증가 가능성}

$\mathrm{ODA}$ 차관의 정의 및 측정방식 변경 이전에도, 민간으로부터 자금을 차입하여 $\mathrm{ODA}$ 를 제공하 는 것이 가능했다.11) 다만 앞서 설명한 바와 같이, 저금리 기조 이후 민간에서 자금을 차입하여 수원국에 제공하는 ODA 차관 중에서 공여국의 추가적인 예산 부담 노력이 없이도 기존의 증여율 을 만족하는 $\mathrm{ODA}$ 차관이 나타나게 되면서, $\mathrm{ODA}$ 차관의 정의 및 측정방식 변경이 이뤼지게 된 것이다. ${ }^{12)}$ 이로 인해 이제는 $\mathrm{ODA}$ 차관으로 인정받기 위해서는 변경된 기준에 의한 수원국 소득 그룹별 할인율을 적용한 후, 최소증여율만 만족하기만 하면 된다. 더욱이 UMIC와 LMIC의 경우 기존의 증여율 $25 \%$ 보다 최소 증여율 기준이 각각 $10 \%$ 와 $15 \%$ 로 낮아졌다는 점에도 최소 증여 율 기준을 맞추기가 상대적으로 더 수월해진 반면, 민간의 입장에서는 UMIC나 LMIC로의 차관 제공이 $\mathrm{LDC}$ 로의 차관 제공보다 더 안정적이라고 받아들여질 가능성도 있다. 즉, 금번 $\mathrm{ODA}$ 차관

$11)$ 개정 전 통계지침(OECD, 2013)과 개정 후 통계지침(OECD, 2016d) 모두 공공과 민간(official and private) 관련 규정 에서, '19. Official transactions are those undertaken by central, state or local government agencies at their own risk and responsibility, regardless of whether these agencies have raised the funds through taxation or through borrowing from the private sector.' 라고 정의하고 있다.

12) 민간으로부터 자금을 차입하여 $\mathrm{ODA}$ 를 제공하는 경우, 해당 자금의 집행에 대한 위험과 책임(상환의무를 공공기관이 지 는 등)을 감수한 경우 ODA로 인정된다. 관련 규정은 OECD DAC 통계지침 19-20번 문장 참고 (20. "responsibility" covers the choice of the purpose of expenditure, the decision as to the terms of a transaction, and the acceptance of the risk involved in undertaking the transaction (i.e. meeting the loss that occurs if the recipient fails to amortise or delays payment on a loan). 
의 측정방식 변경으로 인해, 향후 민간에서 자금을 차입하여 $\mathrm{ODA}$ 차관을 제공을 제공하는 방식 이 더 활성화 될 수 있는 환경이 조성된 것으로 판단된다.

수원국의 채무건전성 등을 고려할 때, $\mathrm{ODA}$ 차관 지원이 늘어나는 것은 긍정적이지 않으나, 현 실적으로 공여국 정부의 $\mathrm{ODA}$ 예산 증액이 쉽지 않은 상황에서, 민간에서 자금을 동원, 차입하여 $\mathrm{ODA}$ 차관으로 인정받을 수 있는 상기 지원방식은 $\mathrm{ODA}$ 의 증액을 도모할 수 있는 현실적인 대안 이 될 수 있음을 부정할 수는 없다. ${ }^{13)}$ 우리나라도 제2차 ODA 기본계획 수립 시, 세수부족으로 인해 기존 $\mathrm{ODA} / \mathrm{GNI}$ 목표치를 하향 조정하였으며, 향후 $\mathrm{ODA}$ 예산의 급격한 증가는 어려울 것 으로 전망하고 있으며, $\mathrm{ODA}$ 목적성에 있어서 역시 국내 기업의 참여를 통한 win-win 전략이 강조되고 있는 상황이다. 단, 유상원조의 급격한 비율 증가나 증여율이 낮은 차관의 증가는 국제 사회에서 비판의 대상이 될 수 있으며, 민간자금을 차입하여 제공한 유상원조라고 하더라도, 채무 불이행에 대한 책임과 의무는 공여국 (공여기관)에 귀속된다는 점을 고려해, 세수를 활용한 유상 원조와 민간차입을 활용한 유상원조를 포괄하는 범정부차원에서 계획 수립 (지역별 배분 등을 고 려) 후 접근하는 것이 바람직할 것으로 보인다.

\section{2. 공적지원으로 인해 동원된 민간재원 측정 범위 확대 필요}

공적지원으로 인해 동원된 민간재원의 규모를 측정하고 보고하고자 하는 노력은 공여국의 민간 재원 동원 노력을 정확하게 측정하고 평가하기 위함이다. 그러나 아직까지 $\mathrm{OECD}$ 통계지침 상 민 간재원 조달 금액을 통계적으로 측정하고 보고하는 수단은 신디케이트론, 보증, CIV에 한정되어 있다. $\mathrm{KOICA}$ 의 경우 전통적으로 민간기업, 시민사회, 대학 등과 다양한 ODA 사업을 공동으로 추진해왔으며, 이 과정에서 matching fund형식으로 민간 (기업, NGO, 대학 등) 에서 재원이 투 입된 경우가 많이 있다. ${ }^{14)}$ 이 경우에도 $\mathrm{KOICA}$ 의 $\mathrm{ODA}$ 사업 수행으로 인해 민간 증여가 동원되

13) 단, 민간자금을 활용하여 개도국에 차관을 제공하는 경우에도 차관의 제공 및 약정 체결 주체, 공여국 정부의 자금 지 원 방식 등에 따라 차입자금이 ODA 차관으로 계상될 수 도 있고, 아닐 수도 있다. 예를 들어, 민간재원을 공여국의 유 상원조 기관(한국의 경우, 한국수출입은행 $\mathrm{EDCF})$ 이 차입하고, 이자 등의 비용(이차보전)을 공여기관 자체 자금으로 제공 한 후, 개도국에 재대출하는 경우에는, 차관제공자(대주)가 수출입은행으로 개도국에 제공한 차관(대출) 총액이 자금흐름 유형(types of flows)은 ODA로 보고(양허성 조건 만족 시)되고, 개도국 소득그룹별 증여율을 적용하여 계산한 증여등가 액만 $\mathrm{ODA}$ 차관으로 보고하게 된다. 그러나 공여기관 자체 자금으로 보전한 이자비용(이차보전액) 자체는 ODA로 보고 불가한데, 그 이유는 이차보전(interest subsidy)을 적용한 후, 증여등가액을 계산하여 차관의 증여등가액 보고하므로, 이 미 ODA에 반영되어 있으므로, 별도 보고 시 이중 계상되기 때문이다. 그런데, 민간이 개도국에 직접 대출을 하고, 공여 기관 자체 자금으로 이자보전을 하여, 시장금리보다 낮은 금리로 개도국이 대출할 수 있게 지원하는 경우에는 차관제공 자(대주)가 민간이 되게 되고, 민간 제공한 대출(차관) 총액은 민간자금(other private flows at market terms)으로 보고 되게 된다. 이 경우, 공여기관 자체자금으로 보전한 이자비용(이차보전액)의 자금흐름유형(types of flows)은 ODA로 보 고되며, 금융수단(financial instrument)은 증여(grant)의 한 유형인 Interest subsidy로 보고해야 한다(상세내용 $\mathrm{OECD}$, 2016d 참조). 
었음에도 불구하고, 무상원조를 통해 동원된 민간 증여는 따로 이를 동원한 노력을 측정하는 방 안이 논의되지 않고 있다. ${ }^{15)}$ 개발목적의 민간 증여의 증가 역시 궁극적으로 SDGs 달성 등 개도 국의 빈곤퇴치 및 경제성장에 기여한다고 볼 수 있으며, KOICA에서 실시하는 CSR 등의 사업에 투입된 민간 지원은 $\mathrm{KOICA}$ 의 지원이 있었기에 민간의 증여가 이뤼졌다는 인과관계의 가정도 성 립이 된다. 따라서 공적지원으로 인한 민간재원 조달 재원의 범위를 확대하여, 이를 포함시키는 논의가 필요할 것으로 판단된다. 더욱이 기업이나 $\mathrm{NGO}$ 등 민간의 $\mathrm{OECD} \mathrm{DAC} \mathrm{통계} \mathrm{상의} \mathrm{'민간}$ 증여 보고'를 자발적 참여에 맡기고 있으며 이를 강제할 수 없는 상황에서, 매칭펀드 형식의 민간 증여 동원액을 공여기관이 보고하게 된다면, 보다 정확한 민간지원액 파악에도 긍정적일 것으로 생각된다.

\section{3. 신규 금융수단 및 민간금융수단을 활용한 사업 다각화 필요}

신규 금융수단과 민간금융수단(PSI)의 도입으로 이제 다양한 방식으로 개도국의 공공부분뿐만 아니라 민간부분을 직접 지원하는 공여국의 노력을 보다 정확하게 측정하고 보고할 수 있는 환경 이 조성되었다. 지속가능발전을 위해서는 사회개발을 넘어 포용적 성장이 이루어져야한다는 국제 사회의 공감 하에, 개도국 기업을 직접 지원해야 하는 사업모델의 중요성이 강조되고 있는 상황 이다. 우리나라뿐만 아니라 KOICA도 기존에 실시16)하고 있는 ODA 사업 중 새로운 금융수단 유 형으로 보고가능하거나, 새롭게 도입할 수 있는 사업 유형이 있는지에 대해 면밀한 분석과 평가 가 필요할 것이다. 도입 가능한 사업유형에 대한 분석 및 사업모델 마련 후에는 아직 시장 환경 이 조성되지 않은 최빈국에서는 민간금융수단을 활용한 지원보다는 전통적인 형태의 무상원조에 대한 필요성이 더 높을 수 있는 점 등을 고려하여, 지역별, 소득수준별 적용 가능한 사업유형을 세분화하여 사업 계획을 수립할 필요가 있다.

\section{TOSSD의 도입으로 인한 ODA 실질 감소 우려 및 구체화 필요}

$\mathrm{TOSSD}$ 의 도입 시 개도국 입장에서는 해당 국가로 유입되는 개발재원을 포괄적으로 파악할 수

14) 이는 기존에 $\mathrm{OECD}$ 에서 수집 및 보고하던 통계 흐름 중 하나인 private charitable flows로 보고 가능, 현재 KOICA는 $\mathrm{NGO}$ 단체 자체자금을 조사하여 '총액'만을 보고하고 있다 (자발적으로 회신한 기관에 한정).

15) 올해 실시된 2016 DAC Survey에서 혼합금융과 PPP 등 복합적인 자금조달 구조를 가진 사업을 조사하며, 무상원조를 통한 민간의 자금조달 사례도 수집한 바 있으나, 이는 별도의 조사로 실시된 것일 뿐 공식 통계로의 도입이 논의 된 것은 아니다.

16) KOICA는 Mango Fund를 통해 우간다 중소기업을 지원한 바 있다. 
있다는 장점이 있으며, 민간의 연계가 용이한 분야까지 TOSSD의 범위로 포괄하고 있다는 점에 서 긍정적으로 평가된다. 또한 TOSSD 논의는 기후재원 조성 논의와도 연계되어 진행되고 있다 는 점에서 그 중요성이 강조되고 있는 상황이다. 그럼에도 불구하고 TOSSD의 논의에도 몇 가지 우려 및 논란이 존재하고 있는 상황이다. 먼저, $\mathrm{OECD}$ 측은 TOSSD가 $\mathrm{ODA}$ 를 대체해서는 안 된 다고 강조하고 있으나, 실질적으로 TOSSD가 $\mathrm{ODA}$ 를 포괄하는 개념으로 성립되고 있는 상황을 고려할 때 $\mathrm{ODA}$ 대체 효과가 발생할 가능성이 적지 않다. 또한 금번 SLM에서 TOSSD의 모니터 링 프레임웍 등 기본 틀에 대한 내용이 제출될 예정이나, TOSSD의 구체적인 범주에 대한 세부 적인 내용은 아직 논의가 시작되지 못한 상황이다.

제 I 장

$$
\text { 개 }
$$

\section{5. 통계 고도화 및 다변화}

끝으로 $\mathrm{ODA}$ 현대화 논의에 의해 민간재원의 동원 및 측정관련 다양한 통계기법이 새롭게 도 입되었고, 증여등가액 방식의 $\mathrm{CRS}$ 통계와 자금흐름 방식의 TOSSD가 병존하게 되는 등 $\mathrm{DAC}$ 통 계가 고도화되고 다변화되었다. DAC 통계의 고도화 및 다변화로 보다 정확하게 공여국의 개발 노력을 측정할 수 있다는 점은 긍정적으로 평가되나, 기존의 통계 보고에 비해 증여등가액 보고 와 자금흐름 보고의 공존, 신규 항목의 추가 등 새로운 보고 항목이 다수 증가하여, 통계 보고 부 담이 증대되었다. 또한 민간재원의 동원, 시장금융수단(PSI)의 측정 등 다변화되고, 다각화된 통 계 구조로 인해 $\mathrm{DAC}$ 통계의 직관적인 이해는 상대적으로 어려졌다는 점에서 우려가 된다. 아직 까지 통계보고 방식이 개발되지 않은 부분도 다수 남아있다는 점도 마찬가지이다. OECD 및 국제 사회에서 진행 중인 통계보고 관련 논의가 조속히 완료될 수 있도록 노력하고, 변경된 통계 기준 에 적합한 $\mathrm{ODA}$ 를 수행하고, 보고하기 위한 정책 및 시행기관의 전방위적 준비와 노력이 필요할 것으로 사료된다. 


\section{〈참고문헌〉}

구윤정. 2015. “OECD DAC의 ODA 재정의와 시사점”. ${ }^{\circledR} \mathrm{EDCF}$ 이슈페이퍼』4(1). 서울: 한국수출입은행

임소진. 2015. "ODA 현대화와 민간재원 II: 민간금융수단(PSI)의 ODA 통계보고".

${ }^{『} \mathrm{EDCF}$ 이슈페이퍼』4(5). 서울: 한국수출입은행

박수영·조한슬. 2015. 『Post-2015체제의 ODA정의 현대화와 총공적개발지원 분석 연구』.

성남: 한국국제협력단

OECD. 2016a. "DAC HIGH Level Meeting Communiqué”. February 19, 2016.

Paris: OECD

2016b. "Implementation of the HLM Agreement on Concessionality:

Treatment of Loans to Multilateral Institutions in DAC Statistics". DCD/DAC(2016)18/REV. Paris: OECD

. 2016c. "Revised Converged Statistical Reporting Directives for the

Creditor Reporting System (CRS) and the Annual DAC Questionnaire". DCD/DAC(2016)3. Paris: OECD

2016d. "Revised Converged Statistical Reporting Directives for the

Creditor Reporting System (CRS) and the Annual DAC Questionnaire Addendum 1". DCD/DAC(2016)3/ADD1. Paris: OECD

. 2016e. "Draft TOSSD Compendium - for public consultation-". June

2016. Paris: OECD

. 2016f. "2016 DAC Survey on Amounts Mobilised from the Private

Sector by Official Development Finance Interventions”. July 2016. Paris: OECD

. 2014a. "DAC HLM Background Paper - Including the Cost of Using Private-Sector Instruments in ODA”. DCD/DAC (2014)64. Paris: OECD

2014b. "Inclusion of the Effort in Using Private-Sector Instruments in

ODA: Exploring Further the Institutional and Instrument-Specific Approaches". DCD/DAC/STAT(2015)3. Paris: OECD 
_ 2014c. "Final Communique of the 2014 DAC High Level Meeting". DCD/DAC(2014)69/FINAL. Paris: OECD

. 2013. "Converged Statistical Reporting Directives for the Creditor

Reporting System(CRS) and the Annual DAC Questionnaire”. DCD/DAC (2013)15/FINAL. Paris: OECD

. 2012a. "UK Discussion Paper on ODA Eligibility of DFI Activity", DCD/DAC/STAT/RD(2012)2/RD5. Paris: OECD

. 2012b. "Proposal for Clarification of Concessional in Character". DCD/DAC/STAT(2012)22. Paris: OECD

제 I 장

개

발

협

력

이

슈

제 II 장

제 피장 


\section{별첨. OECD 통계지침상 금융수단(Types of Finance) 목록}

\begin{tabular}{|c|c|}
\hline 대분류 & 소분류 \\
\hline \multirow{4}{*}{$\begin{array}{l}\text { 증여 } \\
\text { (Grants) }\end{array}$} & Standard grant / 일반 증여 \\
\hline & Interest subsidy / 이자 지원금 \\
\hline & $\begin{array}{l}\text { Capital subscription on deposit basis } \\
\text { 출자기준 자금출자 }\end{array}$ \\
\hline & $\begin{array}{l}\text { Capital subscription on encashment basis } \\
\text { 현금화기준 자금출자 }\end{array}$ \\
\hline \multirow{5}{*}{$\begin{array}{c}\text { 채무수단 } \\
\text { (Debt instruments) }\end{array}$} & Standard loan / 일반 차관 \\
\hline & Reimbursable grant / 상환가능 증여 \\
\hline & Bonds / 채권 \\
\hline & Asset-backed securities / 자산담보부증권 \\
\hline & Other debt securities / 기타 채권 \\
\hline \multirow{3}{*}{$\begin{array}{c}\text { 메자닌 금융수단 } \\
\text { (Mezzanine finance instruments) }\end{array}$} & Subordinated loan / 후순위 차관 \\
\hline & Preferred equity / 우선주 \\
\hline & Other hybrid instruments / 기타 합성자산 \\
\hline \multirow{3}{*}{$\begin{array}{c}\text { 지분투자 및 집합기구주식 } \\
\text { (Equity and shares in collective } \\
\text { investment vehicles) }\end{array}$} & Common equity / 보통주 \\
\hline & $\begin{array}{l}\text { Shares in collective investment vehicles } \\
\text { 집합투자기구 내 주식/지분 }\end{array}$ \\
\hline & Reinvested earnings / 재투자한 수익 \\
\hline $\begin{array}{c}\text { 보증 및 기타 우발채무 } \\
\text { (Guarantees and other } \\
\text { unfunded contingent liabilities) }\end{array}$ & Guarantees/insurance / 보증/보험 \\
\hline \multirow{10}{*}{$\begin{array}{l}\text { 채무구제 } \\
\text { (Debt relief) }\end{array}$} & $\begin{array}{l}\text { Debt forgiveness/conversion: ODA claims (P) } \\
\text { 채무탕감/전환: ODA 채권(원금) }\end{array}$ \\
\hline & $\begin{array}{l}\text { Debt forgiveness/conversion: ODA claims (I) } \\
\text { 채무탕감/전환: ODA 채권 (이자) }\end{array}$ \\
\hline & $\begin{array}{l}\text { Debt forgiveness/conversion: OOF claims (P) } \\
\text { 채무탕감/전환: OOF 채권(원금) }\end{array}$ \\
\hline & $\begin{array}{l}\text { Debt forgiveness/conversion: OOF claims (I) } \\
\text { 채무탕감/전환: OOF 채권(이자) }\end{array}$ \\
\hline & $\begin{array}{l}\text { Debt forgiveness/conversion: Private claims (P) } \\
\text { 채무탕감/전환: 민간 채권(원금) }\end{array}$ \\
\hline & $\begin{array}{l}\text { Debt forgiveness/conversion: Private claims (I) } \\
\text { 채무탕감/전환: 민간 채권(이자) }\end{array}$ \\
\hline & $\begin{array}{l}\text { Debt forgiveness: OOF claims (DSR) } \\
\text { 채무 탕감: OOF 채권(채무상환삭감) }\end{array}$ \\
\hline & $\begin{array}{l}\text { Debt forgiveness: Private claims (DSR) } \\
\text { 채무 탕감: 민간 채권(채무상환삭감 ) }\end{array}$ \\
\hline & $\begin{array}{l}\text { Debt forgiveness : Others } \\
\text { 채무 탕감: 기타 }\end{array}$ \\
\hline & $\begin{array}{l}\text { Debt rescheduling: ODA claims (P) } \\
\text { 채무 재조정: ODA 채권(원금) }\end{array}$ \\
\hline
\end{tabular}




\begin{tabular}{|c|c|}
\hline 대분류 & 소분류 \\
\hline \multirow{17}{*}{$\begin{array}{l}\text { 채무구제 } \\
\text { (Debt relief) }\end{array}$} & $\begin{array}{l}\text { Debt rescheduling: ODA claims (I) } \\
\text { 채무 재조정: ODA 채권(이자) }\end{array}$ \\
\hline & $\begin{array}{l}\text { Debt rescheduling: OOF claims }(P) \\
\text { 채무 재조정: OOF 채권(원금) }\end{array}$ \\
\hline & $\begin{array}{l}\text { Debt rescheduling: OOF claims (I) } \\
\text { 채무 재조정: OOF 채권(이자) }\end{array}$ \\
\hline & $\begin{array}{l}\text { Debt rescheduling: Private claims }(P) \\
\text { 채무 재조정: 민간 채권(원금) }\end{array}$ \\
\hline & $\begin{array}{l}\text { Debt rescheduling: Private claims (I) } \\
\text { 채무 재조정: 민간 채권(이자) }\end{array}$ \\
\hline & $\begin{array}{l}\text { Debt rescheduling: OOF claims (DSR) } \\
\text { 채무 재조정: OOF 채권(채무상환삭감 ) }\end{array}$ \\
\hline & $\begin{array}{l}\text { Debt rescheduling: Private claims (DSR) } \\
\text { 채무 재조정: 민간 채권(채무상환삭감 ) }\end{array}$ \\
\hline & $\begin{array}{l}\text { Debt rescheduling: OOF claim (DSR - original loan principal) } \\
\text { 채무 재조정: OOF 채권(채무상환삭감 - 최초 차관 원금) }\end{array}$ \\
\hline & $\begin{array}{l}\text { Debt rescheduling: OOF claim } \\
\text { 채무 재조정: OOF 채권(채무상환삭감 - 최초 차관 이자) }\end{array}$ \\
\hline & $\begin{array}{l}\text { Debt rescheduling: Private claim (DSR - original loan principal) } \\
\text { 채무 재조정: 민간 채권(채무상환삭감 - 최초 차관 원금) }\end{array}$ \\
\hline & $\begin{array}{l}\text { Debt forgiveness/conversion: export credit claims (P) } \\
\text { 채무 탕감/전환: 수출신용 채권(원금) }\end{array}$ \\
\hline & $\begin{array}{l}\text { Debt forgiveness/conversion: export credit claims (I) } \\
\text { 채무 탕감/전환: 수출신용 채권(이자) }\end{array}$ \\
\hline & $\begin{array}{l}\text { Debt forgiveness: export credit claims (DSR) } \\
\text { 채무 탕감: 수출신용 채권(채무상환삭감) }\end{array}$ \\
\hline & $\begin{array}{l}\text { Debt rescheduling: export credit claims }(P) \\
\text { 채무 재조정: 수출신용 채권(원금) }\end{array}$ \\
\hline & $\begin{array}{l}\text { Debt rescheduling: export credit claims (I) } \\
\text { 채무 재조정: 수출신용 채권(이자) }\end{array}$ \\
\hline & $\begin{array}{l}\text { Debt rescheduling: export credit claims (DSR) } \\
\text { 채무 재조정: 수출신용 채권(채무상환삭감) }\end{array}$ \\
\hline & $\begin{array}{l}\text { Debt rescheduling: export credit claims(DSR - original loan principal) } \\
\text { 채무 재조정: 수출신용 채권(채무상환삭감 - 최초 차관 원금) }\end{array}$ \\
\hline
\end{tabular}

출처 : OECD (2016d) 